\title{
IMPACTS OF SEDIMENTATION ON STONY CORALS
}

\author{
Oleh \\ Tri Aryono Hadi ${ }^{1)}$
}

\begin{abstract}
ABSTRAK
PENGARUH SEDIMENTASI PADA KARANG KERAS. Aktivitas manusia baik di darat maupun di laut membawa banyak pengaruh negatif terhadap ekosistem laut. Terumbu karang yang utamanya disusun oleh karang keras mengalami degradasi akibat turunnya kualitas perairan, terutama akibat sedimentasi dan eutrofikasi. Secara umum hal ini akan menyebabkan menurunnya kelimpahan dan diversitas karang batu, dan secara khusus akan memengaruhi proses fisiologis karang. Proses fotosintesis menurun sebagai imbas dari menurunnya penetrasi cahaya akibat tingginya turbiditas dan sedimen yang menempel di permukaan karang. Untuk menanggulangi defisit energi, maka karang meningkatkan aktivitas menangkap makanan sekaligus proses respirasi. Reproduksi dan rekruitmen juga akan menurun seiring rusaknya sperma karang dan tertutupnya substrat untuk perlekatan larva. Sedimen juga akan memicu penyakit karang karena produksi mukus yang berlebihan. Pengkayaan nutrien di laut akan meningkatkan proses fotosintesis sebagaimana tersedianya senyawa anorganik yang penting untuk transfer energi dan kandungan dari zooxanthellae, namun apabila berlebihan akan menimbulkan gangguan pada proses reproduksi dan meningkatkan wabah penyakit karang. Meskipun karang mampu merespon gangguan tersebut, untuk jangka waktu yang panjang akan menimbulkan effek yang mematikan. Oleh karena itu perlu dilakukannya evaluasi mengenai aktivitas manusia disekitar wilayah pesisir untuk meminimalisir dampak negatif pada ekosistem pesisir.
\end{abstract}

\section{INTRODUCTION}

Coastal development has become a serious threat to marine life. Overexploitation, pollution, habitat transformation have caused marine degradation and biodiversity loss, thus hampering ecological resiliency of ecosystem (Nystrom et al., 2012). It is reported that coral reef and its associated ecosystem, such as seagrasses, have been declining massively in the global scale (Waycott et al., 2009). These losses are more attributable to declining water quality, particularly due to sedimentation (De'ath \& Fabricius, 2010).

There are two major factors which can trigger sedimentation in marine habitats, including terrestrial run off and dredging (Fabricius et al., 2005; Erfteimejer et al., 2012). Terrestrial run off has continually increased sediment transport trough soil

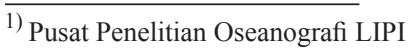


erosion in global rivers by approximately $2.3+0.6$ billion metric tons per year (Syvitski et al., 2005). A study confirms that the impact of dredging activities could reach radius of 250 meters, in condition of dredge head concentration $204.3 \mathrm{mg} / \mathrm{l}$, water velocity $0.3 \mathrm{~m} / \mathrm{s}$ and turbulent diffusion coefficient $22 \mathrm{~m}^{2} / \mathrm{s}$ (Je et al., 2007). Hence, it is predicted that the ecosystems surrounding the sources of sedimentation will be highly impacted.

Coral reefs are commonly perceived as biogenic structure, yet rarely considered that more than a half of the materials in most coral reef complexes is basically made up of sediment (Sorokin, 2013). Sediment on the most coral reefs consists of carbonate (aragonite, high magnesium calcite and calcite) which is produced by the growth and subsequent destruction of reef organisms as well as pre-existing reef rock through biological, chemical and physical processes; and sediment near shore fringing reef contains silicate grains from weathered and eroded igneous or metamorphic rock (terrigenous sediment) (Dudley, 2003). Through the time, loose sediments and the skeleton of primary and secondary organisms might be changed into reef rock and, in the end, it forms a dense solid limestone through consolidation of reef material, binding, cementation and diagenesis (Sorokin, 2013). Sediment is commonly accumulated in inshore reefs and sheltered, wave-protected parts of reef systems, but less accumulated in reef crest and outer reefs as the wave energy becomes increasing (Wolanski et al., 2005).

Sedimentation has contributed to the declining of coral reef habitats, either directly by burial reefs or indirectly as a consequence of lethal and sub lethal stress to corals which result from increased water turbidity (Piniak \& Storlazzi, 2008). The effects may be abrupt or gradual for a longer period and this can be temporary or permanent in nature. Coral responses to sedimentation can be different among species; some of them are resistant and others are very vulnerable, and depend on local environment and vary between seasons (Wolanski et al., 2008). Hence, the impacts of sedimentation on corals are very complex and need to be investigated further.

\section{VARIOUS IMPACTS OF SEDIMENT ON CORALS}

There are some studies which have observed the impacts of sedimentation both resulting from dredging activities and terrestrial run off (Table 1).

Table 1. Impacts of sedimentation and terrestrial run off on corals in different areas

\begin{tabular}{llll}
\hline \multicolumn{1}{c}{ Location } & \multicolumn{1}{c}{ Issues } & \multicolumn{1}{c}{ Impacts } & \multicolumn{1}{c}{ References } \\
\hline Hay Point, Australia & $\begin{array}{l}\text { Dredging for port construction and } \\
\text { expansion with total volume of } \\
\text { dredging up to } 9 \text { million } \mathrm{m}^{3}\end{array}$ & $\begin{array}{l}\text { Coral cover loos up to 2-5 \% at } 2 \text { Smith et al. (2007) } \\
\text { the source }\end{array}$ \\
Singapore & $\begin{array}{l}\text { Coastal reclamation and dredging } \\
\text { along the coastline }\end{array}$ & $\begin{array}{l}\text { Approximately 60\% of coral reefs Hilton \& Manning } \\
\text { has been degraded and the rest was (1995) } \\
\text { subjected to impacts of sediment }\end{array}$
\end{tabular}


East Coast, Bahrain

St. Lucia, Caribbean River sediment

Okinawa, Japan Sediment from the Hija River

Great Barrier Reef, Sediment and nutrient discharge Australia

Great Barrier Reef, Nutrient discharge from rivers Australia

Puerto Rico, Carib- Sediment and nutrient discharge bean Sea from rivers

Dredging and reclamation for beach widening
22 hectares of coral reefs have been in critical conditions due to high turbidity and sedimentation

Approximately 5 hectares of hard Lindeman \& Snybottom habitats have degraded and der (1999)

30 fold loss in fish density

Partial mortality up to $50 \%$ on the Nugues \& Robert most common massive corals and (2003)

fission on the colonies

Corals were highly contaminated by Ramos et al. (2004) heavy metals, particularly by $\mathrm{Pb}$.

Coral cover and richness declined Van Woesik et al. and increased macroalgae and filter (1999)

feeder nearby the shore

Increasing population of Achantaster Brodie et al. (2005) planci in coral reef habitats

Increasing growth of photosynthetic Larsen \& Webb algae and coral reefs were in critical (2009) conditions

These studies confirm that both sedimentation from dredging and terrestrial run off bring negative impacts to coral reefs and enhance growth of macroalgae and $A$. planci as result of nutrient discharge from rivers. Although the studies provide general decline in coral reef conditions, the impact on corals as individual need to be understood. The impacts commonly occur in many aspects, such as physiological processes (photosynthesis, feeding and respiration), reproduction and recruitment, and diseases (Erftemeijer et al., 2012).

\section{a. Photosynthesis process}

The main issue of increasing turbidity and sedimentation is related to shading which can limit the light intensity. Light will exponentially decrease with depth because of attenuation process; in this case the light will be absorbed and scattered by water molecules, dissolved matter and particle solids (Bridge \& Demicco, 2008). The development and maximal growth of reef corals generally occur down to $30-$
$40 \%$ of subsurface irradiance (SI) and it is rarely to find a significant formation of reef below 10\% SI (Achituv \& Dubinsky, 1990). Light intensity also affects corals' growth rates, given that there were variations in growth rate of Montipora monasteriata in the Great Barrier Reef (Anthony \& Hoegh-Gulberg, 2003). Furthermore, a study reports that a linear extension rate of Acropora valenciennesi in sites with low sedimentation rate was approximately $200 \mathrm{~mm} /$ year, while in the highly sedimented sites it was around $90 \mathrm{~mm} /$ year (Crabbe \& Smith, 2005).

Turbidity and sedimentation affect the photosynthesis process as it limits the light penetration. The turbidity will decrease the ambient photosynthetically active radiation (PAR) and cause zooxanthellae productivity to decrease, resulting in starvation (Gilmour et al., 2006). While sedimentation will lead to addition shading and smothering, which can contribute to the decline of photosynthetic activity and even initiate bleaching 
(Anthony et al., 2007). It is reported that sedimentation $\left(79-234 \mathrm{mg} / \mathrm{cm}^{2}\right)$ for 36 hours could reduce approximately 6 fold maximal quantum yield of photosystem II compared to the control treatment, and this also reduced the zooxanthellae density and chlorophyll concentration per unit area (Phillipp \& Fabricious, 2003). Furthermore, a study reports that gross photosynthesis/respiration (P : R Ratio) of Dichocenia stokesii and Meandrina meandrites fell from approximately 1.5 to 0.5 (Telesnicki \& Goldberg, 1995). In addition, Goniastrea retriformis responded to the prolonged shading through both photo and heterotrophic plasticity, yet still could not compensate for the reduced light as daily respiration exceed daily photosynthesis (Anthony \& Fabricius, 2000). The decline in alga productivity can cause nutrition, growth, reproduction and calcification rate to drop (Richmond, 1993). Thus, it is clear that sedimentation and turbidity will affect the photosynthesis process through light availability, resulting in different growth rate of corals.

Nutrient coming from rivers apparently has a positive effect on photosynthesis process. Dissolved Inorganic Nitrogen (DIN) increases the density of zooxanthellae as well as the content of nitrogen and chlorophyll a per zooxanthellae, and promotes photosynthesis process, transfer of energy, $\mathrm{CO} 2$ and nutrient between zooxanthellae and host (Koop et al., 2001). Another kind of nutrient is Dissolved Inorganic Phosphate which was found to enhance the photosynthesis rates of Stylophora pistilata up to $150 \%$ (FerierPages et al., 2000). Although it provides resources for corals' physiological processes, excessive nutrient has potentially negative effects on coral growth and diseases. Nitrogen addition can hamper coral growth and phosphorus can reduce the formation of $\mathrm{CaCO}_{3}$ crystal, making the density become lower (Fabricius, 2005). Furthermore, this issue enhances coral reef degradation by promoting macroalgae growth (Szmant, 2002). Hence, it may conclude that the drawbacks of nutrient discharge from rivers or eutrophication outweighs the benefits.

\section{b. Feeding and Respiration}

Sedimentation and burial bring negative impacts on corals as a sessile organism. Sediment which covers corals' surfaces can initiate smothering of coral polyps (Fabricius \& Wolanski, 2000). Moreover, a study confirms that photosynthesis rate in sediment-exposed corals during day time was decreasing, while the respiration rate during night time was increasing (Abdel-Salam et al., 1988). Sediment on the surface can interfere corals' feeding apparatus; in this case it causes polyps to retract and cease tentacular actions and, if the sedimentation is very high, it will make polyps difficult to expand and eventually corals cannot compensate for the loss of energy from heterotrophic activities (Erftemeijer et al., 2012). However, sediment may bring organic material in which corals can feed on. A study reports that particle ingestion rate of Goniastrea retiformis was correlated positively with concentration of suspended particular matter (SPM) in the range of $1-30 \mathrm{mg}$ dry weight/1; in this case 
the particle feeding has doubled in response to prolonged shading (Anthony \& Fabricius, 2000). In addition, it is reported that high turbidity level on coastal reefs will enhance the lipid stores by 4 and 2 folds for Turbinaria mesenterina and Acropora valida respectively compared to the same offshore species (Anthony, 2006).

\section{c. Reproduction and recruitment}

Coral reproduction and recruitment appear to be more sensitive to environmental changes, and dependent highly on clean water with low sedimentation rate (Humphrey et al., 2008). Suspended sediment inhibits coral fertilization, given that aggregation of eggs becomes more pronounced and this may reduce the success of fertilization, or, alternatively the sediment may hamper or damage the sperm (Gilmour, 1999). There was a significant decline in fertilization process of Acropora millepora by more than 50\% in a treatment with suspended-sediment level at $\geq 100 \mathrm{mg} / 1$ with salinity $30 \mathrm{ppt}$ (Humphrey et al., 2008). Another main cause is inorganic material which affects eggs production. A study reports that Acropora longyciathus which was exposed to increased nitrogen produced significantly fewer and smaller eggs, and even had less testes material compared to those which were in control treatment (Ward \& Harrison, 2000). Furthermore, increased nitrogen also reduces egg fertilization rates by increasing rate of abnormallyformed embryos (Harrison \& Ward, 2001). In addition, planulation of Pocillopora damicornis failed and the egg size was reduced after 4 months exposed to elevated ammonium (Cox \& Ward, 2002).
Settlement and survivorship of larvae are the key factors for recruitment success. Low sediment level, in which it is only cover thinly the corals' surfaces and not directly harmful to adult colonies, can hamper the recruitment process by inhibiting settlement and reducing the survivorship of larvae (Goh \& Lee, 2008). A study confirms that settlement and survivorship of larvae reached only 71 $\%$ and $39 \%$ respectively in a condition in which sedimentation rate ranged between 0.76 - $1.32 \mathrm{mg} \mathrm{cm}^{-2} \mathrm{~d}^{-1}$ (Babcock $\&$ Smith, 2002). Furthermore, 35 percent of recruits have died after a 43 day exposure to transparent exopolymer particle-enriched sediment and the mortality became $80 \%$ as the sediment increased by $50 \%$ (Fabricius et al., 2003).

In summary, declining water quality due to either sedimentation or eutrophication - particularly during spawning time of corals - may affect their reproduction success and hamper coral recruitment. This situation may compromise the resilience of coral reefs. Although the studies were conducted in laboratory, the same issues may possibly occur in natural environment which is polluted.

\section{d. Disease}

Sediment lying down on the corals' surface can initiate mucus production. A potential issue from excessive mucus production is increasing populations of bacteria (Ritchie \& Smith, 2004). The metabolism of bacteria may cause local anoxic conditions and high nutrient content in silt promotes the metabolism of bacteria (Weber et al., 2006). A study in Caribbean 
reef finds that nutrient enrichment could increase severity of yellow band disease on Montastrea annularis and M. franksii (Bruno et al., 2003). Nutrient enrichment can exacerbate the severity of black band diseases (BBD) by promoting migration rate of the infections (Voss \& Richardson, 2006). Furthermore, a study reports that, by using stable isotope analysis, sewage-derived $\mathrm{N}$ was correlated significantly with the increase of severity of disease in Porites spp., accounting for more than $48 \%$ of the change variation in disease severity (Redding et al., 2013). In addition, BBD and white plague type II became more prevalent at sewage-impacted environment (Kaczmarsky et al., 2005). These studies imply that the prevalence of disease can be exacerbated by the nutrient on the sediment, and the sediment causes corals to spend more energy to eradicate sediment in surface, making corals weak and more vulnerable to disease.

\section{RESPONSES OF CORALS TO DIFFERENT ISSUES}

\section{a. Responses of corals to turbidity}

Low light intensity is attributable to high turbidity in water column. This will decrease calcification rate as the photosynthesis productivity declines, being approximately three times lower in darkness compared to normal condition (Gattuso et al., 1999). Although corals obtain limited light intensity, adaptations by zooxanthellae allows maximal absorption and utilization of light; making gross photosynthesis rate increase (Ti- tlyanov, 1991). A study indicates that there was photo-acclimation of Porites lutea in which the light saturation coefficient $\left(\mathrm{E}_{\mathrm{k}}\right)$ and maximum relative electron transport rate $\left(\mathrm{rETR}^{\mathrm{MAX}}\right)$ decreased as the light became limited (Hennige et al., 2008). Furthermore, it is found that community structure of Symbiodinium changed across environmental gradient in the Wakatobi Marine National Park; given that at optimal sites, the types of Symbiodinium were dominated by clade $\mathrm{C}$, while in the impacted sites the most dominant type was clade D (Hennige et al., 2010). Although corals are able to responds the limited light due to turbidity, long term impact of turbidity can cause coral reefs to lose its coral diversity (Done et al., 2007). It is also found that turbidity affects the distribution of corals; Pachyseris, Merulina and Mycedium, which are generally deeper water genera, were found in shallow water in Singapore (Dikou \& Van Woesik, 2006).

\section{b. Responses of corals to sedimentation}

Corals actively remove sediment on its surface to obtain light. Forty two species of corals showed the same mechanism to remove the sediment by ciliary currents, tissue expansion and mucus entanglement, and these capabilities are closely related with calice size; given that rejecting influxes become higher as the size of calice become bigger (Hoeksema \& de Voogd, 2012). However, this active removal is costly and may not remain for long period, therefore dredging activities as the main source of sedimentation, should be monitored thoroughly to prevent environmental degradation (Erftemeijer et al., 2012). 


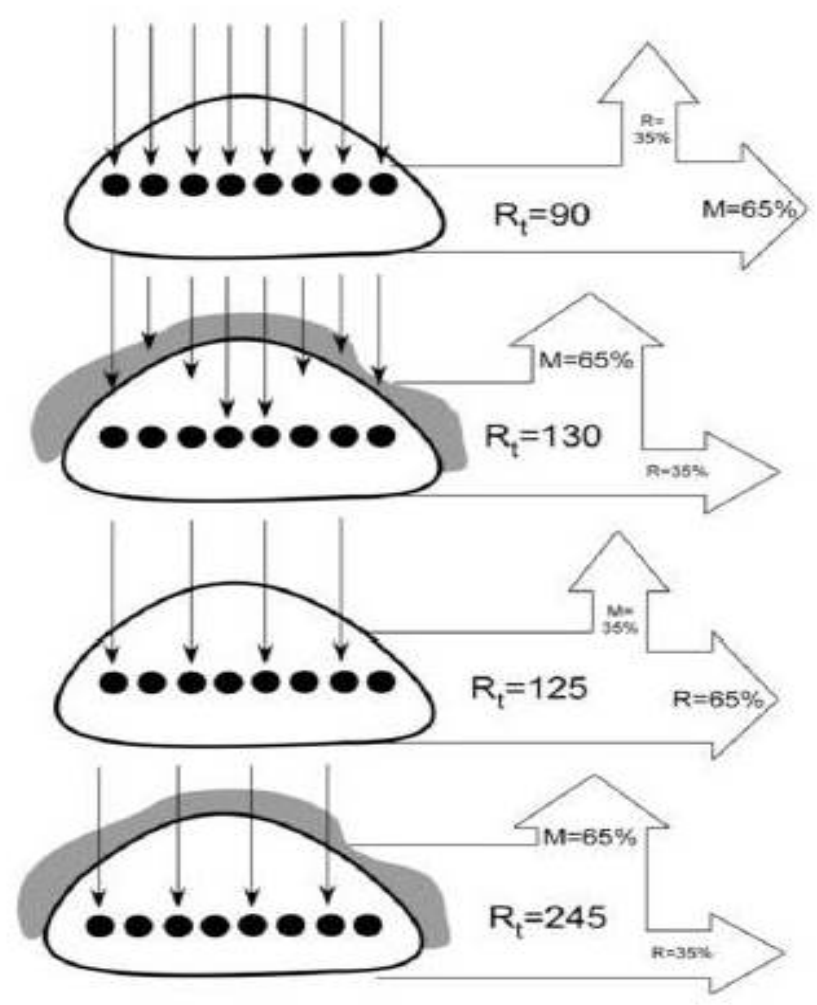

Figure 1. Energy budget of massive corals in encountering sedimentation and turbidity (Erftemeijer et al., 2012).

Figure 1 describes the energy budget when corals encounter high turbidity and sedimentation. The coral in the top receives maximum light and approximately $90 \%$ of productivity will be respired; $35 \%$ of which will be allocated for mucus production, while $65 \%$ will be allocated for metabolic functions. On the other hand, the bottom coral receive the least light intensity and is covered by sediment. In this situation, $245 \%$ of productivity will be utilized; $65 \%$ of which is for mucus production and the rest is used for metabolic function. Under this situation, corals cannot be autotroph as the light is very limited (Erftemeijer et al., 2012).
In summary, impacts of turbidity and sediment can be complicated as corals have to allocate energy budget efficiently. Although some mechanisms can be deployed to adapt with the situation, during this situation corals seem to obtain less energy particularly from photosynthesis. Thus, it will affect ability corals to maintain its colony if the water quality is still poor and, eventually, coral population will decline.

\section{c. Responses of corals to nutrient en- richment}

Nutrient discharge appears to have influence in metabolic functions of corals, such as photosynthesis, growth 
and reproductions (Tanaka et al., 2007). The severe impacts are mostly from the organism which can take benefits from nutrient enrichment, such as bacteria and fungus (Lintlon et al., 2002), Achantaster planci (Brodie et al., 2005), filter feeders animals (Costa Jr. et al., 2000), and macroalgae (Szmant, 2002). In this situation, corals encounter a tough competition with other sessile biotas as well as diseases and predation. However, corals will have more responses in competition as it is not abrupt effect. Coral will inhibit other sessile organisms by overgrowing; shading: abrasion (whiplash); stinging which involves sweeper tentacles and polyps, and mesentrial filament; chemical; and mucus secretion (McCook et al., 2001). However, the responses of coral may depend on the environmental conditions in which corals obtain resources for its energy.

\section{MANAGEMENT OF CORAL REEF ECOSYSTEMS}

The feasible overview to obtain coral reef conditions is through field observation. Baseline data are quite important to understand the conditions before the impacts occur. Monitoring program is very essential to obtain the trend of the conditions. Hence, the solutions over the impact can be implemented after wards. It is also necessary to set the thresholds of each issue, therefore prevention efforts can be proceeded before the issues become more severe. Furthermore, human activities nearby ecosystems needs to be evaluated. In addition, socialization and education to local societies about the importance of coral reef ecosystems need to be improved, therefore, the local can be a part of management system (Sale, 2008).

\section{REFERENCES}

Abdel-Salam, H. A., J. W. Porter and B. Hatcher. 1988. Physiological effects of sediment rejection on photosynthesis and respiration in three $\mathrm{Ca}$ ribbean reef corals. Paper presented at the Proc. 6th int. coral Reef Symp.

Achituv, Y. and Z. Dubinsky. 1990. Evolution and zoogeography of coral reefs. Ecosystems of the world 25: 1-9.

Anthony, K. 2006. Enhanced energy status of corals on coastal, high-turbidity reefs. Marine Ecology Progress Series 319: 111-116.

Anthony, K. and K. E. Fabricius. 2000. Shifting roles of heterotrophy and autotrophy in coral energetics under varying turbidity. Journal of experimental marine biology and ecology, 252(2): 221-253.

Anthony, K. and O. Hoegh-Guldberg. 2003. Kinetics of photoacclimation in corals. Oecologia 134(1): 23-31. 
Anthony, K., S. R. Connolly and O. Hoegh-Guldberg. 2007. Bleaching, energetics, and coral mortality risk: Effects of temperature, light, and sediment regime. Limnology and oceanography 52: 716-726.

Babcock, R. and L. Smith. 2002. Effects of sedimentation on coral settlement and survivorship. Paper presented at the Proceedings of the Ninth International Coral Reef Symposium, Bali, 23-27 October 2000 .

Bridge, J. and R. Demicco. 2008. Earth surface processes, landforms and sediment deposits. Cambridge University Press, Cambridge: 795 hlm.

Brodie, J., K. Fabricius, G. De'ath and K. Okaji. 2005. Are increased nutrient inputs responsible for more outbreaks of crown-of-thorns starfish? An appraisal of the evidence. Marine Pollution Bulletin 51(1): 266-278.

Bruno, J. F., L. E. Petes, C. Drew Harvell and A. Hettinger. 2003. Nutrient enrichment can increase the severity of coral diseases. Ecology Letters 6(12): 1056-1061.

Costa Jr, O., Z. Leao, M. Nimmo and M. Attrill. 2000. Nutrification impacts on coral reefs from northern Bahia, Brazil Is- land, Ocean and Deep-Sea Biology pp: 307-315

Cox, E. F. and S. Ward. 2002. Impact of elevated ammonium on reproduction in two Hawaiian scleractinian corals with different life history patterns. Marine Pollution Bulletin 44(11): 1230-1235.

Crabbe, M. J. C. and D. J. Smith. 2005. Sediment impacts on growth rates of Acropora and Porites corals from fringing reefs of Sulawesi, Indonesia. Coral Reefs 24(3): 437441.

De'ath, G. and K. Fabricius. 2010. Water quality as a regional driver of coral biodiversity and macroalgae on the Great Barrier Reef. Ecological Applications 20(3): 840-850.

Dikou, A. and R. Van Woesik. 2006. Survival under chronic stress from sediment load: spatial patterns of hard coral communities in the southern islands of Singapore. Marine Pollution Bulletin 52(1): 7-21.

Done, T., E. Turak, M. Wakeford, L. DeVantier, A. McDonald and D. Fisk. 2007. Decadal changes in turbid-water coral communities at Pandora Reef: loss of resilience or too soon to tell? Coral Reefs 26(4): 789-805. 
Dudley, W.C. 2003. Coral Reef Sedimentology. http://www.kmec. uhh.hawaii.edu/QUESTInfo/reefsEDM.pdf. Diakses pada Juni 2014.

Erftemeijer, P. L., B. Riegl, B. W. Hoeksema and P. A. Todd. 2012. Environmental impacts of dredging and other sediment disturbances on corals: a review. Marine Pollution Bulletin 64(9): 1737-1765.

Fabricius, K. and E. Wolanski. 2000. Rapid smothering of coral reef organisms by muddy marine snow. Estuarine, Coastal and Shelf Science 50(1): 115-120.

Fabricius, K. E., C. Wild, E. Wolanski and D. Abele. 2003. Effects of transparent exopolymer particles and muddy terrigenous sediments on the survival of hard coral recruits. Estuarine, Coastal and Shelf Science 57(4): 613-621.

Fabricius, K. E. 2005. Effects of terrestrial runoff on the ecology of corals and coral reefs: review and synthesis. Marine pollution bulletin 50(2): 125-146.

Falkowski, P. G., P. L. Jokiel and R. Kinzie. 1990. Irradiance and corals. Ecosystems of the world 25: 89-107.

Ferrier-Pages, C., J. P. Gattuso, S. Dallot and J. Jaubert. 2000. Effect of nutrient enrichment on growth and photosynthesis of the zooxanthellate coral Stylophora pistillata. Coral Reefs 19(2): 103-113.

Gattuso, J. P., D. Allemand and M. Frankignoulle. 1999. Photosynthesis and calcification at cellular, organismal and community levels in coral reefs: a review on interactions and control by carbonate chemistry. American Zoologist 39(1): 160-183.

Gilmour, J. 1999. Experimental investigation into the effects of suspended sediment on fertilisation, larval survival and settlement in a scleractinian coral. Marine Biology 135(3): 451-462.

Gilmour, J. J., T. T. Cooper, K. Fabricius and L. Smith. 2006. Early warning indicators of change in the condition of corals and coral communities in response to key anthropogenic stressors in the Pilbara, Western Australia: Executive Summary and Future Recommendations. http:// www3.aims.gov.au/bitstream/handle/11068/7212/ PilbaraCoralMonitoring.pdf?sequence $=1$. Diakses pada Juni 2014.

Glynn, P. W. 1996. Coral reef bleaching: facts, hypotheses and implications. Global Change Biology 2(6): 495-509. 
Goh, B. and C. Lee. 2008. A study of the effect of sediment accumulation on the settlement of coral larvae using conditioned tiles. Paper presented at the Proceedings Eleventh International Coral Reef Symposium, Ft. Lauderdale, Florida.

Harrison, P. and S. Ward. 2001. Elevated levels of nitrogen and phosphorus reduce fertilisation success of gametes from scleractinian reef corals. Marine Biology 139(6): 1057-1068.

Hennige, S. J., D. J. Smith, R. Perkins, M. Consalvey, D. M. Paterson and D. J. Suggett. 2008. Photoacclimation, growth and distribution of massive coral species in clear and turbid waters. Marine Ecology Progress Series 369: 7788.

Hennige, S. J., D. J. Smith, R. Perkins, M. Consalvey, D. M. Paterson and D. J. Suggett. 2008. Photoacclimation, growth and distribution of massive coral species in clear and turbid waters. Marine Ecology Progress Series 369: 7788.

Hilton, M. J. and S. S. Manning. 1995. Conversion of coastal habitats in Singapore: indications of unsustainable de- velopment. Environmental Conservation 22(04), 307322.

Hoeksema, B. and N. De Voogd. 2012. On the run: free-living mushroom corals avoiding interaction with sponges. Coral Reefs 31(2): 455-459.

Humphrey, C., M. Weber, C. Lott, T. Cooper and K. Fabricius. 2008. Effects of suspended sediments, dissolved inorganic nutrients and salinity on fertilisation and embryo development in the coral Acropora millepora (Ehrenberg, 1834). Coral Reefs 27(4): 837-850.

Je, C. H., D. F. Hayes and K. S. Kim. 2007. Simulation of resuspended sediments resulting from dredging operations by a numerical flocculent transport model. Chemosphere 70(2): 187-195.

Kaczmarsky, L. T., M. Draud and E. H. Williams. 2005. Is there a relationship between proximity to sewage effluent and the prevalence of coral disease. Caribb J Sci 41(1): 124-137.

Koop, K., D. Booth, A. Broadbent, J. Brodie, D. Bucher, D. Capone and $\mathrm{P}$. Harrison, $\mathrm{P}$. 2001. ENCORE: the effect of nutrient enrichment on coral reefs. Synthesis 
of results and conclusions. Marine Pollution Bulletin 42(2): 91-120.

Larsen, M. C. and R. M. Webb. 2009. Potential effects of runoff, fluvial sediment, and nutrient discharges on the coral reefs of Puerto Rico. Journal of Coastal Research 189-208.

Lindeman, K. C. and D. B. Snyder. 1999. Nearshore hardbottom fishes of southeast Florida and effects of habitat burial caused by dredging. Fishery Bulletin 97(3): 508-525.

Linton, D., R. Smith, P. Alcolado, C. Hanson, P. Edwards, R. Estrada and T. Fisher. 2002. Status of coral reefs in the northern Caribbean and Atlantic node of the GCRMN. AIMS, Townsville (Australia): $14 \mathrm{hlm}$.

McCook, L., J. Jompa and G. Diaz-Pulido. 2001. Competition between corals and algae on coral reefs: a review of evidence and mechanisms. Coral Reefs 19(4): 400-417.

Nugues, M. M. and C. M. Roberts. 2003. Partial mortality in massive reef corals as an indicator of sediment stress on coral reefs. Marine Pollution Bulletin 46(3): 314-323.

Nyström, M., A. V. Norström, T. Blenckner, M. de la Torre-Castro,
J. S. Eklöf, C. Folke and M. Troell. 2012. Confronting feedbacks of degraded marine ecosystems. Ecosystems 15(5): 695-710.

Philipp, E. and K. Fabricius. 2003. Photophysiological stress in scleractinian corals in response to short-term sedimentation. Journal of experimental marine biology and ecology 287(1): 57-78.

Piniak, G. A. and C. D. Storlazzi. 2008. Diurnal variability in turbidity and coral fluorescence on a fringing reef flat: Southern Molokai, Hawaii. Estuarine, Coastal and Shelf Science 77(1): 56-64.

Ramos, A., Y. Inoue and S. Ohde. 2004. Metal contents in Porites corals: Anthropogenic input of river run-off into a coral reef from an urbanized area, Okinawa. Marine Pollution Bulletin 48(3): 281-294.

Redding, J. E., R. L. Myers-Miller, D. M. Baker, M. Fogel, L. J. Raymundo and K. Kim. 2013. Link between sewage-derived nitrogen pollution and coral disease severity in Guam. Marine pollution bulletin 73(1): 57-63.

Richmond, R. H. 1993. Coral reefs: present problems and future concerns resulting from anthropogenic disturbance. 
American Zoologist 33(6):

524-536.

Ritchie, K. B. and G. W. Smith. 2004. Microbial communities of coral surface mucopolysaccharide layers. Coral health and disease pp: 259-264.

Sale, P. F. 2008. Management of coral reefs: where we have gone wrong and what we can do about it. Marine Pollution Bulletin 56(5): 805-809.

Sorokin, Y. I. 2013. Coral reef ecology (Vol. 102). Springer Science \& Business Media, Berlin: $463 \mathrm{hlm}$.

Syvitski, J. P., C. J. Vörösmarty, A. J. Kettner and P. Green. 2005. Impact of humans on the flux of terrestrial sediment to the global coastal ocean. Science 308(5720): 376380.

Smith, A., T. Foster, E. Corcoran and J. Monkivitch, J. 2007. Dredging and material relocation in sensitive coral environments. In Proceedings 18th World Dredging Congress (WODCON XVIII) (pp. 945-955).

Szmant, A. M. 2002. Nutrient enrichment on coral reefs: is it a major cause of coral reef decline? Estuaries 25(4): 743-766.

Tanaka, Y., T. Miyajima, I. Koike, T.
Hayashibara and H. Ogawa. 2007. Imbalanced coral growth between organic tissue and carbonate skeleton caused by nutrient enrichment. Limnology and oceanography 52(3): 1139-1146.

Telesnicki, G. J. and W. M. Goldberg. 1995. Effects of turbidiy on the photosynthesis and respiration of two south florida reef coral species. Bulletin of Marine Science 57(2): 527-539.

Titlyanov, E. 1991. The stable level of coral primary production in a wide light range Coelenterate Biology: Recent Research on Cnidaria and Ctenophora pp: 383-387.

Van Woesik, R., T. Tomascik and S. Blake. 1999. Coral assemblages and physico-chemical characteristics of the Whitsunday Islands: evidence of recent community changes. Marine and Freshwater Research 50(5): 427440.

Voss, J. D. and L. L. Richardson. 2006. Nutrient enrichment enhances black band disease progression in corals. Coral Reefs 25(4): 569-576.

Ward, S. and P. Harrison. 2000. Changes in gametogenesis and fecundity of acroporid corals that were exposed to elevated 
nitrogen and phosphorus during the ENCORE experiment. Journal of experimental marine biology and ecology 246(2): 179-221.

Waycott, M., C. M. Duarte, T. J. Carruthers, R. J. Orth, W. C. Dennison, S. Olyarnik and A. R. Hughes. 2009. Accelerating loss of seagrasses across the globe threatens coastal ecosystems. Proceedings of the National Academy of Sciences 106(30): 12377-12381.

Weber, M., C. Lott, and K. Fabricius. 2006. Sedimentation stress in a scleractinian coral exposed to terrestrial and marine sediments with contrasting physical, organic and geochemical properties. Journal of experimental marine biology and ecology 336(1): 18-32.
Wolanski, E., K. Fabricius, S. Spagnol and R. Brinkman. 2005. Fine sediment budget on an inner-shelf coral-fringed island, Great Barrier Reef of Australia. Estuarine, Coastal and Shelf Science 65(1): 153-158.

Wolanski, E., K. E. Fabricius, T. F. Cooper and C. Humphrey. 2008. Wet season fine sediment dynamics on the inner shelf of the Great Barrier Reef. Estuarine, Coastal and Shelf Science 77(4): 755-762.

Zainal, A. J. M., D. H. Dalby and I. S. Robinson. 1993. Monitoring marine ecological changes on the east coast of Bahrain with Landsat TM. Photogrammetric Engineering and Remote Sensing;(United States), 59(3). 